\title{
ANALISIS KESULITAN SISWA DALAM MENYELESAIKAN SOAL MATERI TRANSFORMASI GEOMETRI
}

\author{
Fitri Indah Maulani ${ }^{1}$, Luvy Sylviana Zanthy ${ }^{2}$ \\ Pendidikan Matematika, IKIP Siliwangi ${ }^{1,2}$ \\ fitriindah.maulani11@gmail.com ${ }^{1}$ \\ zanthy23@yahoo.com ${ }^{2}$
}

\begin{abstract}
Abstrak
Penelitian ini bertujuan untuk mengetahui kesulitan siswa dengan melihat kesalahan dan faktor yang menyebabkan siswa melakukan kesalahan dalam menyelesaikan soal materi transformasi geometri. Metode penelitian yang digunakan adalah penelitian deskriptif dengan menggunakan pendekatan kualitatif. Subjek penelitian ini adalah 30 orang siswa kelas XII SIJA A di SMK Negeri 1 Cimahi yang telah mempelajari materi transformasi geometri. Dari hasil tes yang diberikan, kesalahan yang paling banyak terjadi pada submateri dilatasi yaitu hanya $10 \%$ atau hanya 3 orang siswa yang menjawab dengan benar. Kesalahan yang paling sedikit tejadi pada submateri translasi yaitu $40 \%$ atau 12 orang siswa yang menjawab dengan benar. Secara keseluruhan kesalahan siswa kelas XII SIJA A dominan berbentuk kesalahan konsep dan disebabkan oleh cara belajar yang tidak kontinu, kurangnya usaha yang dilakukan dalam mengerjakan soal yang diberikan, tidak teliti dan tergesa-gesa dalam menyelesaikan soal yang diberikan..
\end{abstract}

Kata Kunci: Analisis kesalahan, Transformasi geometri.

\begin{abstract}
This research aims to determine the difficulties of students by looking at errors and factors that cause students to make mistakes in solving geometrical transformation material problems. The research method used is descriptive research using a qualitative approach. The subjects of this research were 30 students of class XII SIJA A at SMK Negeri 1 Cimahi who had studied geometry transformation material. From the results of the tests given, the most common errors in submission dilatation were only 10\% or only 3 students who answered correctly. The least error occurred in translational submissions is $40 \%$ or 12 students who answered correctly. Overall errors of class XII SIJA A are dominant in the form of concept errors and are caused by the way of learning that is not continuous, the lack of effort made in working on a given problem, inaccurate and in a hurry in completing the given questions.
\end{abstract}

Keywords: Error analysis, Geometry transformation.

\section{PENDAHULUAN}

Matematika merupakan salah satu mata pelajaran yang mempunyai peranan penting dalam pendidikan, karena matematika merupakan ilmu universal dimana artinya matematika digunakan dalam berbagai disiplin ilmu. Pentingnya peranan matematika juga terlihat pada pengaruhnya terhadap mata pelajaran lain. Purwasih [1] mengemukakan bahwa "Kebutuhan matematika pada zaman sekarang ialah memahami konsep matematika yang diterapkan untuk mencari solusi dari masalah matematika dan ilmu lainnya". Menurut Lukman \& Zanthy [2] Matematika ialah salah satu dari beberapa mata pelajaran di sekolah yang sangat penting serta erat kaitannya dengan aktivitas yang dilakukan semua individu. Siswa dalam belajar matematika hendaknya mampu mengaitkan pengetahuan yang telah dimiliki dengan pengetahuan yang sedang siswa pelajari. 
Materi geometri penting untuk dipelajari, salah satu alasan pentingnya mempelajari materi geometri yaitu untuk mengasah kemampuan siswa dalam matematika. Hal ini sejalan dengan pendapat Schwartz (Paradesa) [3] "Geometri adalah sebuah konsep yang menghubungkan berbagai bidang dalam matematika". Dengan mempelajari geometri siswa dapat menghubungkan antara konsep matematika yang bersifat abstrak dengan konsep matematika yang bersifat konkret sehingga mudah mengaitkan antara keduanya dan dapat menjadi stimulus terhadap pemahaman yang mendalam. Meskipun demikian, faktanya dilapangan bahwa materi geometri masih kurang dikuasai oleh sebagian besar siswa. Berdasarkan pengalaman beberapa guru matematika, salah satu materi yang sulit dipahami oleh siswa adalah materi transformasi geometri.

Penelitian yang sudah dilakukan Albab, Hartono, \& Darmawijoyo [4] "Siswa mengalami kesulitan dalam memahami konsep transformasi meliputi translasi, refleksi, rotasi dan kombinasi transformasi tersebut". Selain itu, siswa juga kurang dalam pehaman mengenai bagaimana suatu bangun direfleksikan atau dicerminkan. "Kesulitan lain yang siswa alami salah satunya berkaitan dengan arah transformasi" menurut Schultz ( Albab, Hartono, \& Darmawijoyo) [4].

Kesulitan itu dapat terlihat dalam proses menyelesaikan soal materi transformasi geometri. Seperti pendapat Dedy S. Priatna (Widiyanti \& Yani) [6] : mengatakan "Jika seorang siswa mengalami kesulitan maka siswa akan membuat kesalahan". Berdasarkan pendapat di atas berarti kesalahan merupakan sumber utama untuk mengetahui kesulitan siswa dalam menyelesaikan soal-soal transformasi geometri. Kesalahan yang dilakukan siswa tidak hanya terjadi secara kebetulan. Kesalahan siswa dalam menyelesaikan soal terlihat saat menggunakan dan menerapkan prosedur atau langkah-langkah untuk menyelesaikan soal-soal transformasi geometri. Kesalahan siswa dalam menyelesaikan soal-soal transformasi geometri perlu digali untuk memperoleh kejelasan informasi mengapa siswa melakukan kesalahan. Menyadari akan lemahnya kemampuan siswa dalam menyelesaikan tranformasi geometri, maka penulis menganalisis kesalahan siswa dalam menyelesaikan soal-soal transformasi geometri sehingga dapat diketahui jenis-jenis kesalahan yang dialami siswa dapat diminimalisirkan kesalahan siswa dan hasil belajar mencapai standar ketuntasan minimum.

\section{METODE}

Jenis penelitian ini adalah penelitian deskriptif dengan menggunakan pendekatan kualitatif. Penelitian ini menjelaskan kesulitan siswa dalam menyelesaikan persoalan materi transformasi geometri. Subjek penelitian ini adalah 30 orang siswa kelas XII SIJA A di SMK Negeri 1 Cimahi. Teknik pengumpulan data yang digunakan pada penelitian ini adalah tes transformasi geometri dan wawancara. Data yang diharapkan berupa hasil pekerjaan siswa langsung pada lembar soal beserta langkah-langkahnya. Tujuan tes tranformasi geometri adalah untuk mengetahui kesulitan siswa dalam menyelesaikan persoalan transformasi geometri dan wawancara dilaksanakan berdasarkan pedoman yang telah disusun. Data yang diperoleh berupa jawaban-jawaban subjek penelitian secara langsung mengenai tes transformasi geometri. Jawaban-jawaban subjek penelitian berdasarkan wawancara digunakan sebagai triangulasi. 


\section{HASIL DAN PEMBAHASAN}

Tujuan penelitian ini adalah memaparkan jenis-jenis kesalahan dan penyebab kesalahan yang berasal dari dalam diri siswa yang terdapat pada materi transformasi geometri. Sampel pada penelitian berjumlah 30 siswa di kelas XII SIJA A di SMK Negeri 1 Cimahi. Kesalahan yang paling banyak terjadi pada submateri dilatasi yaitu hanya $10 \%$ atau hanya 3 orang siswa yang menjawab dengan benar. Kesalahan yang paling sedikit tejadi pada submateri translasi yaitu $40 \%$ atau 12 orang siswa yang menjawab dengan benar. Karena tujuan penelitian ini hanya memaparkan jenis kesalahan dan penyebab kesalahan dari setiap jawaban siswa yang dijadikan sampel penelitian. Jadi, analisis penyajian datanya tidak memperhatikan data berupa skor nilai.

Langkah pertama yang dilakukan peneliti adalah menghitung jumlah siswa yang menjawab benar, menjawab salah dan tidak menjawab pada tiap butir soal. Langkah kedua yang dilakukan adalah mendeskripsikan hasil jawaban salah pada setiap butir soal dan menganalisis data-data tersebut untuk menjawab pertanyaan penelitian yang pertama. Selanjutnya, dilakukan analisis terhadap data-data dari hasil wawancara untuk menjawab pertanyaan penelitian yang kedua.

\section{Deskripsi Jawaban Siswa}

Dibawah ini disajikan tabel persentase siswa yang menjawab soal dengan benar, menjawab salah dan tidak menjawab pada tiap butir soal

TABEL 1 Jumlah siswa yang menjawab benar, menjawab salah dan tidak menjawab pada tiap butir soal

\begin{tabular}{ccccccc}
\hline $\begin{array}{c}\text { No } \\
\text { Soal }\end{array}$ & $\begin{array}{c}\text { Benar } \\
(\Sigma)\end{array}$ & $\begin{array}{c}\text { Persentase } \\
(\boldsymbol{\%})\end{array}$ & $\begin{array}{c}\text { Salah } \\
(\Sigma)\end{array}$ & $\begin{array}{c}\text { Persentase } \\
(\boldsymbol{\%})\end{array}$ & $\begin{array}{c}\text { Tidak menjawab } \\
(\Sigma)\end{array}$ & $\begin{array}{c}\text { Persentase } \\
(\boldsymbol{\%})\end{array}$ \\
\hline 1 & 6 & $20 \%$ & 16 & $53 \%$ & 8 & $27 \%$ \\
2 & 12 & $40 \%$ & 14 & $47 \%$ & 4 & $13 \%$ \\
3 & 4 & $13 \%$ & 17 & $57 \%$ & 9 & $30 \%$ \\
4 & 10 & $33 \%$ & 16 & $53 \%$ & 4 & $13 \%$ \\
5 & 3 & $10 \%$ & 15 & $50 \%$ & 12 & $20 \%$ \\
\hline
\end{tabular}

Hasil tes yang disajikan pada table 1 menunjukkan bahwa siswa yang menjawab benar pada soal nomor 1 sebanyak 6 orang, yang tidak menjawab ada 8 orang dan menjawab salah sebanyak 16 orang atau sebesar $53 \%$. Siswa yang menjawab benar pada soal nomor 2 sebanyak 12 orang, tidak menjawab sebanyak 4 orang dan yang menjawab salah sebanyak 14 orang atau sebesar $47 \%$. Siswa yang menjawab benar pada soal nomor 3 sebanyak 4 orang, tidak menjawab sebanyak 9 orang dan yang menjawab salah sebanyak 17 orang atau sebesar $57 \%$. Siswa yang menjawab benar pada soal nomor 4 sebanyak 10 orang, tidak menjawab sebanyak 4 orang dan yang menjawab salah sebanyak 16 orang atau sebesar $53 \%$. Siswa yang menjawab benar pada soal nomor 5 sebanyak 3 orang, yang tidak menjawab 12 orang dan yang menjawab salah sebanyak 15 orang atau sebesar $50 \%$. Kesalahan yang paling banyak terjadi pada submateri refleksi transformasi geometri yaitu 57\% (17 siswa). Kesalahan yang paling sedikit terjadi pada submateri translasi transformasi geometri $47 \%$ (14 siswa). Submateri yang paling banyak tidak diketahui siswa adalah submateri dilatasi transformasi geometri yaitu $20 \%$ (12 siswa). Submateri yang paling sedikit tidak diketahui siswa adalah submateri translasi dan rotasi transformasi geometri yaitu 13\% (4 siswa). 
Berdasarkan hasil tes, dapat dilihat bahwa masih banyak siswa yang melakukan kesalahan pada tiap butir soal. Juga terdapat beberapa siswa yang tidak mengerjakan soal. Ada 2 siswa yang paling banyak melakukan kesalahan konsep transformasi geometri secara keseluruhan, ini terlihat dari saat wawancara mereka tidak memberikan alasan dari jawaban yang terdapat dalam tes yang mereka kerjakan. Karena tidak ada alasan yang diberikan maka dapat disimpulkan mereka tidak mengetahui konsep.

Berdasarkan hasil tes diketahui siswa yang melakukan kesalahan dan siswa yang tidak melakukan kesalahan. Kemudian peneliti menyelidiki kembali apakah siswa benar-benar menuliskan jawaban berdasarkan pengetahuan mereka atau hanya asal menjawab soal tersebut dengan melakukan wawancara. Peneliti meminta siswa yang banyak melakukan kesalahan untuk menjelaskan bagaimana siswa menyelesaikan soal yang diberikan. Hasilnya didapat bahwa siswa menjawab dengan sembarang paling banyak terjadi pada konsep translasi transformasi geometri yaitu 40\% (12 siswa). Dan siswa dengan inisial GR merupakan yang paling banyak menjawab dengan sembarang memberikan alasan yaitu $80 \%$ (4 soal). Kebanyakan siswa melakukan kesalahan pada konsep refleksi transformasi geometri. Hal ini terjadi karena mereka tidak memahami konsep rumus refleksi.

\section{Deskripsi Profil Kesalahan Siswa}

Bagian ini akan dideskripsikan kesalahan yang dilakukan siswa dalam menganalisis hasil tes yang dijawab salah pada setiap langkah jawaban untuk masing-masing soal. Untuk hasil jawaban siswa yang tidak menjawab dianggap salah.

\section{Soal nomor 1}

Indikator: Siswa dapat menyelesaikan masalah yang berkaitan dengan transformasi translasi.

- Seorang pendaki sedang berada pada posisi koordinat (a, -b), kemudian ia bergerak ke arah kiri sebanyak 2 a langkah dan ke bawah b+3 langkah kemudian dilanjutkan kembali bergerak ke kiri 3a langkah dan ke atas $2+b$ langkah. Jika a dan b merupakan bilangan bulat. Berada pada koordinat berapakah Posisi pendaki tersebut berhenti?

Hasil jawaban siswa disajikan dalam bentuk tabel sebagai berikut. 
Jurnal Gammath, Volume 5 Nomor 1, Maret 2020

TABEL 2 Jawaban Siswa yang Salah Pada Soal Nomor 1

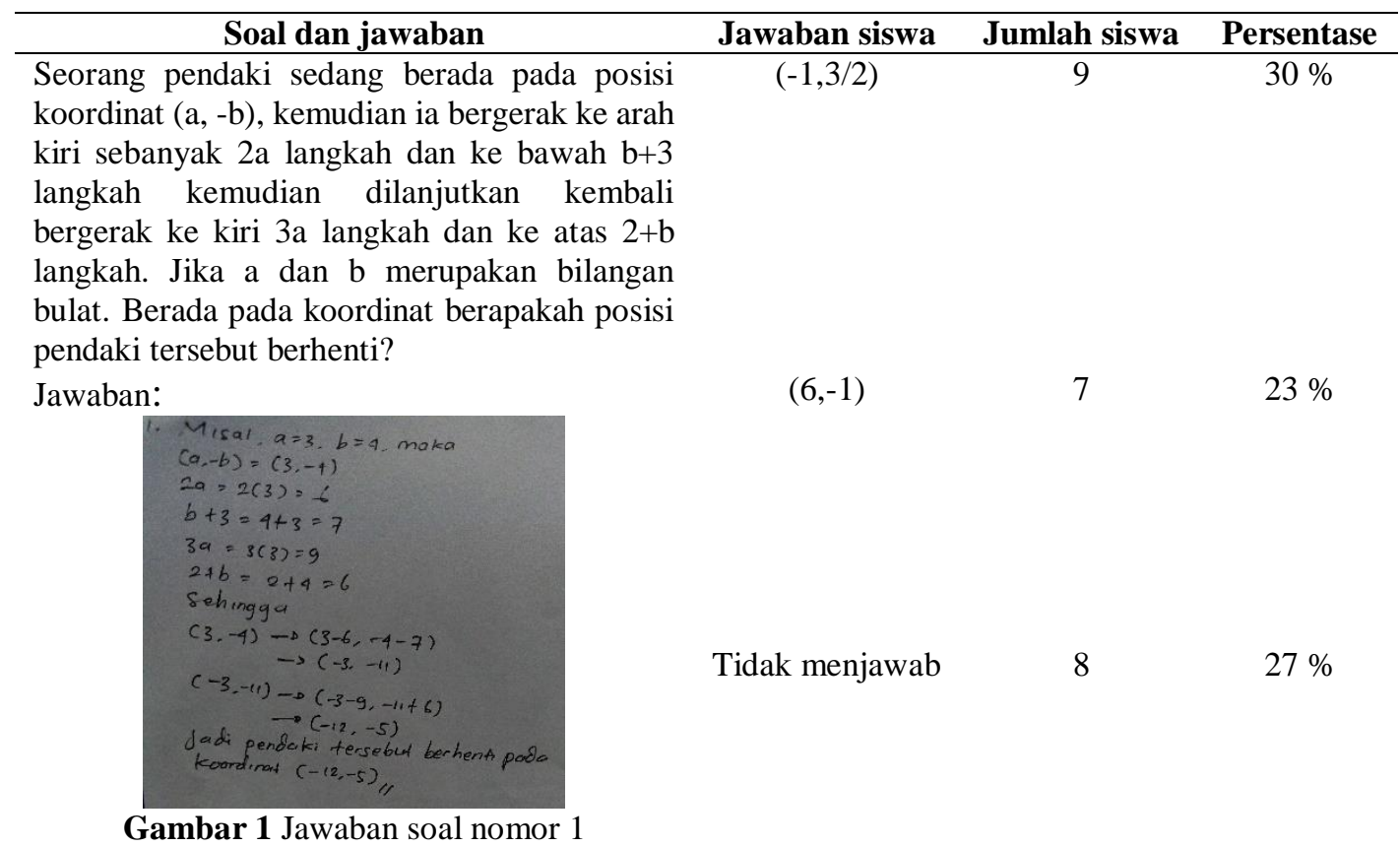

Hasil tes yang disajikan pada tabel 2 menunjukkan bahwa dari jumlah siswa yang salah sebanyak 24 orang sebesar $80 \%$, sisanya sebanyak 6 siswa menjawab soal nomor 1 dengan benar.

Soal nomor 2

Indikator: Siswa dapat menyelesaikan masalah terkait perpindahan posisi benda menggunakan model matematematika translasi.

- Sebuah kotak yang terbuat dari bahan plastik berisi ikan yang akan diekspor ke luar negeri pada mulanya berada pada koordinat $(2,3),(5,0),(9,4)$ dan $(6,7)$. Kemudian kotak tersebut digeser sejauh 5 langkah ke kiri dan 3 langkah ke atas. Pada koordinat berapakah posisi dari kotak yang berisi ikan tersebut setelah mengalami pegeseran? Buatlah model matematika dari permasalahan tersebut!

Berikut ini disajikan hasil jawaban siswa dalam menjawab soal nomor 2 
TABEL 3 Jawaban Siswa yang Salah Pada Soal Nomor 2

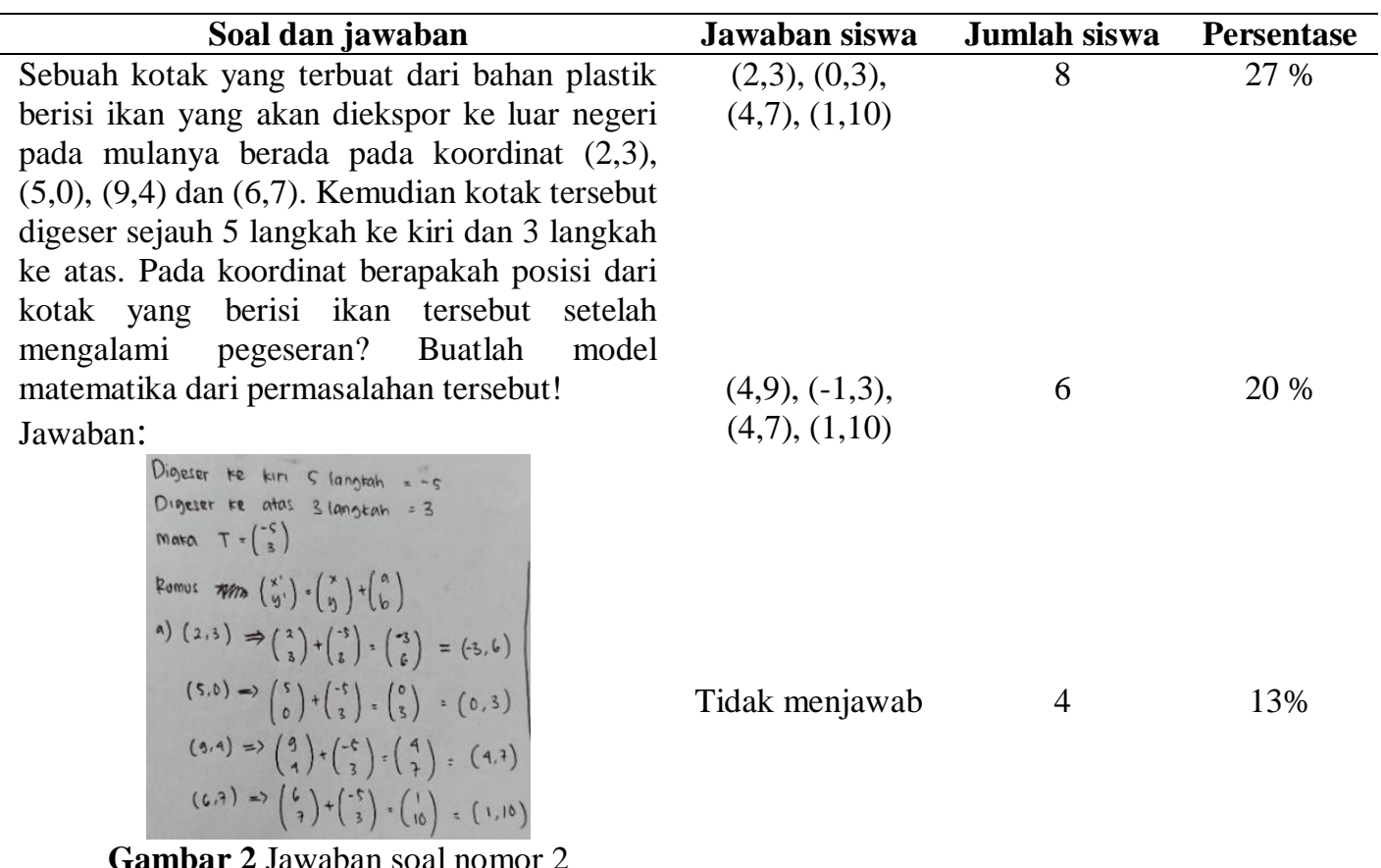

Hasil tes yang disajikan pada tabel 3 menunjukkan bahwa dari jumlah siswa yang salah sebanyak 18 orang sebesar $60 \%$, sisanya sebanyak 12 siswa menjawab soal nomor 2 dengan benar.

Soal nomor 3

Indikator: Siswa dapat mengidentifikasi posisi bayangan 5 orang dengan menggunakan konsep refleksi.

- Terdapat 5 orang anggota klub menari, mereka sedang melakukan latihan dimana setiap orang memiliki posisi masing-masing. Jika posisi masingmasing mereka adalah $(1,1),(3,2),(6,3),(-2,2)$ dan $(-4,4)$ serta mereka sedang melakukan latihan di depan cermin dengan membentuk barisan horizontal. Berdasarkan permasalahan di atas, sajikanlah masalah tersebut dalam bentuk:
a. Gambar
b. Rumus
c. Persamaan

Dibawah ini disajikan tabel hasil jawaban siswa untuk soal nomor 3 
Jurnal Gammath, Volume 5 Nomor 1, Maret 2020

TABEL 4 Jawaban Siswa yang Salah Pada Soal Nomor 3

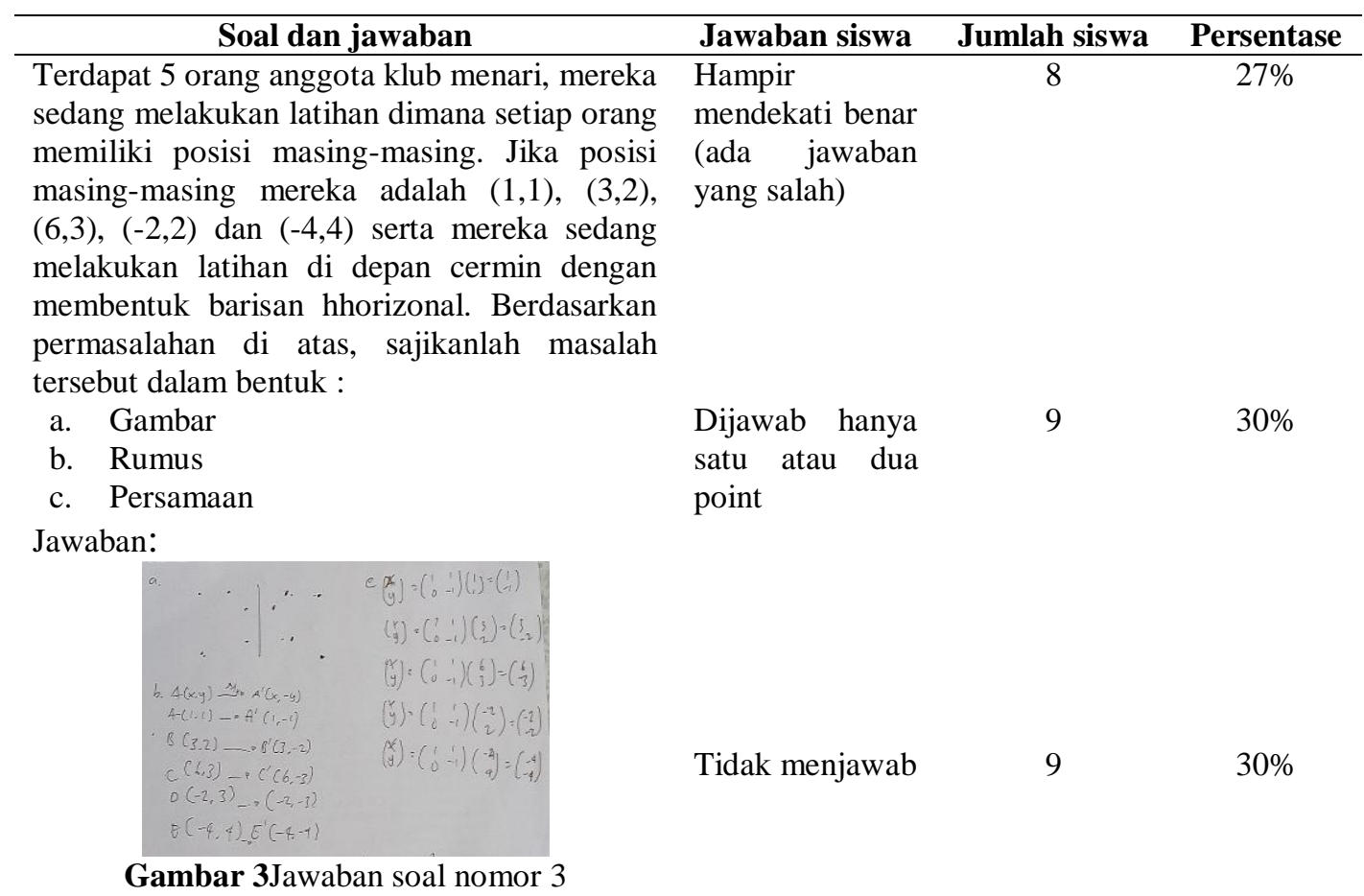

Hasil tes yang disajikan pada tabel 4 menunjukkan bahwa dari jumlah siswa yang salah sebanyak 26 orang sebesar $87 \%$, sisanya sebanyak 4 siswa menjawab soal nomor 3 dengan benar.

Soal nomor 4

Indikator: siswa mampu mengidentfikasi permasalahan terkait sebuah garis yang dirotasikan melalui pusat rotasi.

- Perhatikan gambar dibawah ini!

Sebuah $\triangle \mathrm{ABC}$ diputar pada titik $\mathrm{D}$ dengan sudut putar $90^{\circ}$, kemudian dilanjutkan dengan sudut putar $180^{\circ}$, apabila putarannya searah jarum jam, benarkah gambar $\triangle \mathrm{A}$ "B"C" merupakan bayangan akhir dari $\triangle \mathrm{ABC}$ ? Jelaskan jawabanmu!

Berikut ini disajikan hasil jawaban siswa dalam menjawab soal nomor 4 
TABEL 5 Jawaban Siswa yang Salah Pada Soal Nomor 4

\begin{tabular}{|c|c|c|c|}
\hline Soal dan jawaban & Jawaban siswa & Jumlah siswa & Persentase \\
\hline $\begin{array}{l}\text { Perhatikan gambar dibawah ini! } \\
\text { Sebuah } \triangle \mathrm{ABC} \text { diputar pada titik D dengan } \\
\text { sudut putar } 90^{\circ} \text {, kemudian dilanjutkan dengan } \\
\text { sudut putar } 180^{\circ} \text {, apabila putarannya searah } \\
\text { jarum jam, benarkah gambar } \triangle \mathrm{A}^{\prime} \mathrm{B} \text { "C" } \\
\text { merupakan bayangan akhir dari } \triangle \mathrm{ABC} \text { ? } \\
\text { Jelaskan jawabanmu! }\end{array}$ & $\begin{array}{l}\text { Menjawab iya } \\
\text { dengan argumen } \\
\text { yang tidak jelas }\end{array}$ & 8 & $27 \%$ \\
\hline Jawaban: & & & \\
\hline 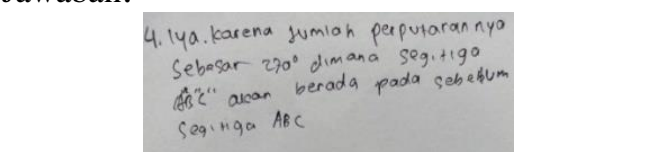 & $\begin{array}{l}\text { Menjawab } \\
\text { dengan argumen } \\
\text { tidak }\end{array}$ & 8 & $27 \%$ \\
\hline & Tidak menjawab & 4 & $13 \%$ \\
\hline
\end{tabular}

Hasil tes yang disajikan pada tabel 5 menunjukkan bahwa dari jumlah siswa yang salah sebanyak 20 orang sebesar $67 \%$, sisanya sebanyak 10 siswa menjawab soal nomor 4 dengan benar.

Soal nomor 5

Indikator: Siswa mampu mengidentifikasi posisi bayangan titik oleh dilatasi.

- Bayangan titik $A(3,-2)$ oleh dilatasi dengan pusat $Q(5,1)$ dan faktor skala -3 adalah $A^{\prime}$. Bayangan titik $\mathrm{B}(1,4)$ oleh dilatasi dengan pusat $\mathrm{P}(-3,0)$ faktor skala $3 / 2$ adalah B'. Carilah koordinat A' dan B' secara geometri menggunakan alat matematika yang disediakan!

Hasil jawaban siswa disajikan dalam bentuk tabel sebagai berikut

TABEL 6 Jawaban Siswa yang Salah Pada Soal Nomor 5

\begin{tabular}{|c|c|c|c|}
\hline Soal dan jawaban & Jawaban siswa & Jumlah siswa & Persentase \\
\hline $\begin{array}{l}\text { Bayangan titik } \mathrm{A}(3,-2) \text { oleh dilatasi dengan } \\
\text { pusat } \mathrm{Q}(5,1) \text { dan faktor skala }-3 \text { adalah } \mathrm{A}^{\prime} \text {. } \\
\text { Bayangan titik } \mathrm{B}(1,4) \text { oleh dilatasi dengan } \\
\text { pusat } \mathrm{P}(-3,0) \text { faktor skala } 3 / 2 \text { adalah } \mathrm{B} \text { '. } \\
\text { Carilah koordinat } \mathrm{A}^{\prime} \text { dan } \mathrm{B} \text { ' secara geometri } \\
\text { menggunakan alat matematika yang } \\
\text { disediakan! }\end{array}$ & $(0,-5)$ dan $(-2,1)$ & 8 & $27 \%$ \\
\hline Jawaban: & $(4,7)$ dan $(-3 / 2,6)$ & 7 & $23 \%$ \\
\hline
\end{tabular}

Gambar 5Jawaban soal nomor 5 
Hasil tes yang disajikan pada table 6 menunjukkan bahwa dari jumlah siswa yang salah sebanyak 27 orang sebesar $90 \%$, sisanya sebanyak 3 siswa menjawab soal nomor 5 dengan benar.

Hasil analisis data Pada soal nomor 1 dengan indikator: siswa dapat menyelesaikan masalah yang berkaitan dengan transformasi translasi, persentase kesulitan sebesar $80 \%$. Hal ini menunjukkan kategori kesulitan sangat tinggi. Berdasarkan kategori kesulitan pada indikator tersebut sedang, maka dapat diartikan bahwa rata-rata siswa mengalami kesulitan dalam menyelesaikan masalah berkaitan dengan transformasi translasi. Penyebab dari siswa yang mengalami kesulitan dalam menyelesaikan masalah berkaitan dengan transformasi translasi yaitu siswa tidak memahami soal dan konsep permasalahan yang berkaitan dengan transformasi translasi. Selain itu siswa juga mengalami kebingungan dalam mengambil identitas yang ada dengan konsepnya.

Persentase kesulitan pada soal nomor 2 dengan indikator: siswa dapat menyelesaikan masalah terkait perpindahan posisi benda menggunakan model matematematika translasi, persentase kesulitan sebesar $60 \%$. Hal ini menunjukkan kategori kesulitan sedang. Berdasarkan kategori kesulitan pada indikator tersebut mudah, maka dapat diartikan bahwa rata-rata siswa mengalami kesulitan dalam memecahkan masalah terkait perpindahan posisi benda. Penyebab dari siswa yang mengalami kesulitan dalam memecahkan masalah terkait perpindahan posisi benda yaitu siswa tidak memahami konsep rumus translasi serta salah dalam pengoperasian rumus translasi.

Persentase kesulitan pada soal nomor 3 dengan indikator: siswa dapat mengidentifikasi posisi bayangan 5 orang dengan menggunakan konsep refleksi, persentase kesulitan sebesar $87 \%$. Hal ini menunjukkan kategori kesulitan sangat tinggi. Berdasarkan kategori kesulitan pada indikator tersebut sedang, maka dapat diartikan bahwa rata-rata siswa mengalami kesulitan dalam mengidentifikasi posisi bayangan 5 orang dengan menggunakan konsep refleksi. Penyebab dari siswa yang mengalami kesulitan dalam mengidentifikasi posisi bayangan 5 orang dengan menggunakan konsep refleksi yaitu siswa tidak memahami konsep rumus refleksi serta lupa bagaimana rumus refleksi.

Persentase kesulitan pada soal nomor 4 dengan indikator: siswa mampu mengidentfikasi permasalahan terkait sebuah garis yang dirotasikan melalui pusat rotasi, persentase kesulitan sebesar $67 \%$. Hal ini menunjukkan kategori kesulitan sedang. Berdasarkan kategori kesulitan pada indikator tersebut mudah, maka dapat diartikan bahwa rata-rata siswa mengalami kesulitan dalam mengidentfikasi permasalahan terkait sebuah garis yang dirotasikan melalui pusat rotasi. Penyebab dari siswa yang mengalami kesulitan dalam mengidentfikasi permasalahan terkait sebuah garis yang dirotasikan melalui pusat rotasi yaitu siswa tidak memahami konsep rumus rotasi serta lupa bagaimana rumus rotasi.

Persentase kesulitan pada soal nomor 5 dengan indikator: Siswa mampu mengidentifikasi posisi bayangan titik oleh dilatasi, persentase kesulitan sebesar $90 \%$. Hal ini menunjukkan kategori kesulitan sangat tinggi. Berdasarkan kategori kesulitan pada indikator tersebut sulit, maka dapat diartikan bahwa rata-rata siswa mengalami kesulitan dalam mengidentifikasi posisi bayangan titik oleh dilatasi. Penyebab dari siswa yang mengalami kesulitan dalam mengidentifikasi posisi bayangan titik oleh dilatasi yaitu siswa tidak memahami konsep rumus dilatasi serta kesalahan dalam pengoperasian konsep dilatasi. 


\section{Analisis data tentang faktor penyebab terjadinya kesalahan}

Analisis data tentang terjadinya kesalahan siswa dalam penelitian ini menggunakan data hasil wawancara terhadap 8 siswa yang telah dipilih untuk setiap jenis kesalahan. Secara umum, faktor penyebab siswa melakukan kesalahan yang dapat dari hasil wawancara adalah siswa tidak dapat memahami materi tansformasi geometri yang baik dan benar. Itu disebabkan karena siswa tidak memahami konsep materi transformasi geometri.

Berdasarkan wawancara analisis jawaban siswa dalam menyelesaikan soal, secara garis besar kesalahan-kesalahan yang dilakukan siswa terjadi karena kurangnya penguasaan konsep terhadap materi transformasi geometri. Ada beberapa penyebab siswa melakukan kesalahan dalam menyelesaikan soal transformasi geometri, yaitu cara belajar yang tidak kontinu, kurangnya usaha yang dilakukan dalam mengerjakan soal yang diberikan, siswa kurang menguasai konsep matematika, dan siswa tidak teliti dan tergesa-gesa dalam menyelesaikan soal yang diberikan

\section{KESIMPULAN}

Berdasarkan hasil analisis data dan pembahasan, maka hasil penelitian ini dapat disimpulkan (1)kesalahan yang dilakukan siswa kelas XII SIJA A di SMK Negeri 1 Cimahi dominannya adalah kesalahan konsep. Penyebab kesalahan yang dilakukan siswa kelas XII SIJA A di SMK Negeri 1 Cimahi diantaranya cara belajar yang tidak kontinu, kurangnya usaha yang dilakukan dalam mengerjakan soal yang diberikan, siswa kurang menguasai konsep materi transformasi geometri, dan siswa tidak teliti dan tergesa-gesa dalam menyelesaikan soal yang diberikan.

\section{DAFTAR RUJUKAN}

[1] Purwasih, R. (2015). Peningkatan Kemampuan Pemahaman Matematis dan Self Confidence Siswa MTS Di Kota Cimahi Melalui Model Pembelajaran Inkuiri Terbimbing, 9, 16-25.

[2] Lukman, S., \& Zanthy, L. S. (2019). Analisis kesalahan siswa SMK dalam memecahkan masalah literasi matematis pada materi bangun ruang, 2(3), 101-105.

[3] Paradesa, R. (2016). Pengembangan Bahan Ajar Geometri Transformasi Berbasis Visual, 2(1), 56-84.

[4] Albab, I. U., Hartono, Y., \& Darmawijoyo. (2014). Kemajuan Belajar Siswa pada Geometri Transformasi Menggunakan Aktivitas Refleksi Geometri, (3), 338-348.

[5] Widiyanti, P., \& Yani, A. (2015). Analisis kesulitan siswa dalam menyelesaikan soal materi pecahan bentuk aljabar di kelas VIII SMP, 1-17. 